\title{
A Glimpse on Trends and Characteristics of Recent Articles Published in the Korean Journal of Radiology
}

\author{
Yeon Hyeon Choe, MD, PhD \\ Department of Radiology, Samsung Medical Center, Sungkyunkwan University School of Medicine, Seoul, Korea; Heart Vascular Stroke Institute, \\ Samsung Medical Center, Sungkyunkwan University School of Medicine, Seoul, Korea
}

One of the aims of the Korean Journal of Radiology (KJR) is to publish trendy articles of high academic interest. KJR started to publish articles on deep learning or artificial intelligence as many other journals are interested in them (1-14). KJR also welcomes articles on radiomics (1, 1517), other advanced imaging techniques, and new imaging systems (18-50). KJR increasingly publishes meta-analyses $(2,51-60)$, and guidelines $(19,31,61-79)$, and KJR also publishes consensus statements and recommendations (67, 80-82) in collaboration with Korean Society of Radiology or other societies $(68,78,83,84)$. Trends show increasing number of published articles with a prospective design and/ or multicenter involvement in the studies $(2,20,21,49$, $50,85-127)$. The numbers of articles with guidelines or consensus statements/recommendations were one in 2016, three in 2017, four in 2018, and 12 in 2019. The numbers of articles with prospective studies were $9(13.0 \%$ of 69 original articles) in 2016, 7 (10.9\% of 64 original articles) in 2017,15 (13.4\% of 112 original articles) in 2018, and $13(12.0 \%$ of 108 original articles) in 2019. Six (5.4\%) and nine $(8.3 \%)$ multicenter studies were published in 2018 and in 2019 , respectively.

Among the articles published in the period from 2017 to 2018 , top 37 articles with citations of 6 or more as of December 8, 2019 in the Web of Science core collection

Corresponding author: Yeon Hyeon Choe, MD, PhD, Department of Radiology, Samsung Medical Center, Sungkyunkwan University School of Medicine, 81 Irwon-ro, Gangnam-gu, Seoul 06351, Korea.

- Tel: (822) 3410-2509 • Fax: (822) 3410-2559

- E-mail:yhchoe@skku.edu

This is an Open Access article distributed under the terms of the Creative Commons Attribution Non-Commercial License (https://creativecommons.org/licenses/by-nc/4.0) which permits unrestricted non-commercial use, distribution, and reproduction in any medium, provided the original work is properly cited. journals included 23 original articles, 10 reviews, and 6 guidelines or consensus statements. Among them, radiofrequency ablation, thyroid imaging and intervention, liver imaging, and cardiovascular imaging contributed for six articles, respectively $(4,6,17,24,29-31,47,49,50$, $69,73,74,81,104,109,112,114,128-146)$. Top 10 KJR articles that had been read most in 0ctober 2019 included four articles on thyroid imaging or intervention and six practice guidelines or consensus statements $(6,21,61,68$, $69,71,81,126,147,148)$.

\section{ORCID iD}

Yeon Hyeon Choe

https://orcid.org/0000-0002-9983-048X

\section{REFERENCES}

1. Park S, Lee SM, Do KH, Lee JG, Bae W, Park H, et al. Deep learning algorithm for reducing $\mathrm{CT}$ slice thickness: effect on reproducibility of radiomic features in lung cancer. Korean $\mathrm{J}$ Radiol 2019;20:1431-1440

2. Kim DW, Jang HY, Kim KW, Shin Y, Park SH. Design characteristics of studies reporting the performance of artificial intelligence algorithms for diagnostic analysis of medical images: results from recently published papers. Korean J Radiol 2019;20:405-410

3. Choi JS, Han BK, Ko ES, Bae JM, Ko EY, Song SH, et al. Effect of a deep learning framework-based computeraided diagnosis system on the diagnostic performance of radiologists in differentiating between malignant and benign masses on breast ultrasonography. Korean J Radiol 2019;20:749-758

4. Yoo YJ, Ha EJ, Cho YJ, Kim HL, Han M, Kang SY. Computeraided diagnosis of thyroid nodules via ultrasonography: initial clinical experience. Korean J Radiol 2018;19:665-672

5. Ahn SY, Chae KJ, Goo JM. The potential role of grid-like 
software in bedside chest radiography in improving image quality and dose reduction: an observer preference study. Korean J Radiol 2018;19:526-533

6. Lee JG, Jun S, Cho YW, Lee H, Kim GB, Seo JB, et al. Deep Learning in medical imaging: general overview. Korean $\mathrm{J}$ Radiol 2017;18:570-584

7. Hong J. Medical Augmented Reality and Virtual Reality. J Korean Soc Radiol 2019;80:226-238

8. Kim JH. Imaging informatics: a new horizon for radiology in the era of artificial intelligence, big data, and data science. J Korean Soc Radiol 2019;80:176-201

9. Weikert T, Cyriac J, Yang S, Nesic I, Parmar V, Stieltjes B. A practical guide to artificial intelligence-based image analysis in radiology. Invest Radiol 2020;55:1-7

10. Nensa F, Demircioglu A, Rischpler C. Artificial intelligence in nuclear medicine. J Nucl Med 2019;60(Suppl 2):29S-37S

11. Martín Noguerol T, Paulano-Godino F, Martín-Valdivia MT, Menias C0, Luna A. Strengths, weaknesses, opportunities, and threats analysis of artificial intelligence and machine learning applications in radiology. J Am Coll Radiol 2019;16(9 Pt B):1239-1247

12. Geras KJ, Mann RM, Moy L. Artificial intelligence for mammography and digital breast tomosynthesis: current concepts and future perspectives. Radiology 2019;293:246259

13. Kim H, Jung DC, Choi BW. Exploiting the vulnerability of deep learning-based artificial intelligence models in medical imaging: adversarial attacks. J Korean Soc Radiol 2019;80:259-273

14. Song KD, Kim M, Do S. The latest trends in the use of deep learning in radiology illustrated through the stages of deep learning algorithm development. J Korean Soc Radiol 2019;80:202-212

15. Park YW, Choi YS, Ahn SS, Chang JH, Kim SH, Lee SK. Radiomics MRI phenotyping with machine learning to predict the grade of lower-grade gliomas: a study focused on nonenhancing tumors. Korean J Radiol 2019;20:1381-1389

16. Park JE, Park SY, Kim HJ, Kim HS. Reproducibility and generalizability in radiomics modeling: possible strategies in radiologic and statistical perspectives. Korean $\mathrm{J}$ Radiol 2019;20:1124-1137

17. Lee M, Woo B, Kuo MD, Jamshidi N, Kim JH. Quality of radiomic features in glioblastoma multiforme: impact of semi-automated tumor segmentation software. Korean $\mathrm{J}$ Radiol 2017;18:498-509

18. Koh J, Kim MJ. Introduction of a new staging system of breast cancer for radiologists: an emphasis on the prognostic stage. Korean J Radiol 2019;20:69-82

19. Kim TH, Yoon JH, Lee JM. Emerging role of hepatobiliary magnetic resonance contrast media and contrast-enhanced ultrasound for noninvasive diagnosis of hepatocellular carcinoma: emphasis on recent updates in major guidelines. Korean J Radiol 2019;20:863-879

20. Kim BM, Park KY, Lee JW, Chung J, Kim DJ, Kim DI. A newly- developed flow diverter (FloWise) for internal carotid artery aneurysm: results of a pilot clinical study. Korean J Radiol 2019;20:505-512

21. Joo I, Kim SY, Park HS, Lee ES, Kang HJ, Lee JM. Validation of a new point shear-wave elastography method for noninvasive assessment of liver fibrosis: a prospective multicenter study. Korean J Radiol 2019;20:1527-1535

22. Choe J, Kim KW, Kim HJ, Kim DW, Kim KP, Hong SM, et al. What is new in the 2017 World Health Organization classification and 8th American Joint Committee on Cancer staging system for pancreatic neuroendocrine neoplasms? Korean J Radiol 2019;20:5-17

23. Venderink W, Jenniskens SF, Michiel Sedelaar JP, Tamada T, Fütterer $\mathrm{JJ}$. Yield of repeat targeted direct in-bore magnetic resonance-guided prostate biopsy (MRGB) of the same lesions in men having a prior negative targeted MRGB. Korean J Radiol 2018;19:733-741

24. Lee DH, Lee JM. Recent advances in the image-guided tumor ablation of liver malignancies: radiofrequency ablation with multiple electrodes, real-time multimodality fusion imaging, and new energy sources. Korean J Radiol 2018;19:545-559

25. Kang Y, Lee E, Lee JW, Kim SR, Kang MJ, Choi YW, et al. Effect of poly(lactide-co-glycolide) nanoparticles on local retention of fluorescent material: an experimental study in mice. Korean J Radiol 2018;19:950-956

26. Ahn S, Jung S, Kim JY, Shin JH, Hahn SY, Oh YL. Evaluation of modified core-needle biopsy in the diagnosis of thyroid nodules. Korean J Radiol 2018;19:656-664

27. O'Neill AC, Jagannathan JP, Ramaiya NH. Evolving cancer classification in the era of personalized medicine: a primer for radiologists. Korean J Radiol 2017;18:6-17

28. Lim S, Rhim H, Lee MW, Song KD, Kang TW, Kim YS, et al. New radiofrequency device to reduce bleeding after core needle biopsy: experimental study in a porcine liver model. Korean J Radiol 2017;18:173-179

29. Kim PK, Hong YJ, Im DJ, Suh YJ, Park CH, Kim JY, et al. Myocardial T1 and T2 mapping: techniques and clinical applications. Korean J Radiol 2017;18:113-131

30. Goo HW, Goo JM. Dual-energy CT: new horizon in medical imaging. Korean J Radiol 2017;18:555-569

31. ASCI Practice Guideline Working Group; Beck KS, Kim JA, Choe YH, Hian SK, Hoe J, Hong YJ, et al. 2017 multimodality appropriate use criteria for noninvasive cardiac imaging: expert consensus of the Asian Society of Cardiovascular Imaging. Korean J Radiol 2017;18:871-880

32. Baheti AD, Jagannathan JP, $0^{\prime}$ Neill A, Tirumani $H$, Tirumani $\mathrm{SH}$. Current concepts in non-gastrointestinal stromal tumor soft tissue sarcomas: a primer for radiologists. Korean $\mathrm{J}$ Radiol 2017;18:94-106

33. Kim M, Kim HS. Emerging techniques in brain tumor imaging: what radiologists need to know. Korean J Radiol 2016;17:598-619

34. Yoo HJ, Lee JS, Lee JM. Integrated whole body MR/PET: where are we? Korean J Radiol 2015;16:32-49 
35. Lee K, Shin Y, Huh J, Sung YS, Lee IS, Yoon KH, et al. Recent issues on body composition imaging for sarcopenia evaluation. Korean J Radiol 2019;20:205-217

36. Kim TM, Choi YH, Cheon JE, Kim WS, Kim IO, Park JE, et al. Optimal kiloelectron volt for noise-optimized virtual monoenergetic images of dual-energy pediatric abdominopelvic computed tomography: preliminary results. Korean J Radiol 2019;20:283-294

37. Hendriks BMF, Schnerr RS, Milanese G, Jeukens CRLPN, Niesen S, Eijsvoogel NG, et al. Computed tomography pulmonary angiography during pregnancy: radiation dose of commonly used protocols and the effect of scan length optimization. Korean J Radiol 2019;20:313-322

38. Yin XP, Gao BL, Li CY, Zhou H, Zhao L, Zheng YT, et al. Optimal monochromatic imaging of spectral computed tomography potentially improves the quality of hepatic vascular imaging. Korean J Radiol 2018;19:578-584

39. Liu G, Li M, Li G, Li Z, Liu A, Pu R, et al. Assessing the blood supply status of the focal ground-glass opacity in lungs using spectral computed tomography. Korean J Radiol 2018;19:130-138

40. Kim YS, Kim SH, Ryu HS, Han JK. Iodine quantification on spectral detector-based dual-energy CT enterography: correlation with Crohn's disease activity index and external validation. Korean J Radiol 2018;19:1077-1088

41. Xing Y, Zhao Y, Guo N, Pan CX, Azati G, Wang YW, et al. Effect of a novel intracycle motion correction algorithm on dual-energy spectral coronary CT angiography: a study with pulsating coronary artery phantom at high heart rates. Korean J Radiol 2017;18:881-887

42. Chung HW, Ko SM, Hwang HK, So Y, Yi JG, Lee EJ. Diagnostic performance of coronary CT angiography, stress dualenergy CT perfusion, and stress perfusion single-photon emission computed tomography for coronary artery disease: comparison with combined invasive coronary angiography and stress perfusion cardiac MRI. Korean J Radiol 2017; 18:476-486

43. Thacker PG, Lee EY. Advances in multidetector CT diagnosis of pediatric pulmonary thromboembolism. Korean $\mathrm{J}$ Radiol 2016;17:198-208

44. Song I, Yi JG, Park JH, Kim SM, Lee KS, Chung MJ. Virtual non-contrast CT using dual-energy spectral CT: feasibility of coronary artery calcium scoring. Korean J Radiol 2016;17:321-329

45. Lee KH, Lee KW, Park JH, Han K, Kim J, Lee SM, et al. Nodule classification on low-dose unenhanced $\mathrm{CT}$ and standarddose enhanced CT: inter-protocol agreement and analysis of interchangeability. Korean J Radiol 2018;19:516-525

46. Lee KB, Goo HW. Quantitative image quality and histogrambased evaluations of an iterative reconstruction algorithm at low-to-ultralow radiation dose levels: a phantom study in chest CT. Korean J Radiol 2018;19:119-129

47. Goo HW. Is it better to enter a volume CT dose index value before or after scan range adjustment for radiation dose optimization of pediatric cardiothoracic CT with tube current modulation? Korean J Radiol 2018;19:692-703

48. Kim DJ, Park MK, Jung DE, Kang JH, Kim BM. Radiation dose reduction without compromise to image quality by alterations of filtration and focal spot size in cerebral angiography. Korean J Radiol 2017;18:722-728

49. Oh SW, Cheon GJ. Prostate-specific membrane antigen PET imaging in prostate cancer: opportunities and challenges. Korean J Radiol 2018;19:819-831

50. Becker AS, Perucho JA, Wurnig MC, Boss A, Ghafoor S, Khong $\mathrm{PL}$, et al. Assessment of cervical cancer with a parameterfree intravoxel incoherent motion imaging algorithm. Korean J Radiol 2017;18:510-518

51. Kim PH, Choi SH, Kim JH, Park SH. Comparison of radioembolization and sorafenib for the treatment of hepatocellular carcinoma with portal vein tumor thrombosis: a systematic review and meta-analysis of safety and efficacy. Korean J Radiol 2019;20:385-398

52. Kim DW, Suh CH, Kim KW, Pyo J, Park C, Jung SC. Technical performance of two-dimensional shear wave elastography for measuring liver stiffness: a systematic review and metaanalysis. Korean J Radiol 2019;20:880-893

53. Chung SR, Choi YJ, Suh CH, Lee JH, Baek JH. Diffusionweighted magnetic resonance imaging for predicting response to chemoradiation therapy for head and neck squamous cell carcinoma: a systematic review. Korean J Radiol 2019;20:649-661

54. Wang WD, Zhang LH, Ni JY, Jiang XY, Chen D, Chen YT, et al. Radiofrequency ablation combined with transcatheter arterial chemoembolization therapy versus surgical resection for hepatocellular carcinoma within the Milan criteria: a metaanalysis. Korean J Radiol 2018;19:613-622

55. Choi SH, Kim JW, Kim JH, Kim KW. Efficacy and safety of microwave ablation for malignant renal tumors: an updated systematic review and meta-analysis of the literature since 2012. Korean J Radiol 2018;19:938-949

56. Zhu ZX, Liao MH, Wang XX, Huang JW. Transcatheter arterial chemoembolization plus ${ }^{131} \mathrm{I}$-labelled metuximab versus transcatheter arterial chemoembolization alone in intermediate/advanced stage hepatocellular carcinoma: a systematic review and meta-analysis. Korean J Radiol 2016;17:882-892

57. Wang X, Hu Y, Ren M, Lu X, Lu G, He S. Efficacy and safety of radiofrequency ablation combined with transcatheter arterial chemoembolization for hepatocellular carcinomas compared with radiofrequency ablation alone: a time-to-event metaanalysis. Korean J Radiol 2016;17:93-102

58. Suh CH, Park SH. Successful publication of systematic review and meta-analysis of studies evaluating diagnostic test accuracy. Korean J Radiol 2016;17:5-6

59. Lee J, Kim KW, Choi SH, Huh J, Park SH. Systematic review and meta-analysis of studies evaluating diagnostic test accuracy: a practical review for clinical researchers-Part II. Statistical methods of meta-analysis. Korean J Radiol 
2015;16:1188-1196

60. Kim KW, Lee J, Choi SH, Huh J, Park SH. Systematic review and meta-analysis of studies evaluating diagnostic test accuracy: a practical review for clinical researchers-Part I. General guidance and tips. Korean J Radiol 2015;16:11751187

61. Lee JW, Hur JH, Yang DH, Lee BY, Im DJ, Hong SJ, et al. Guidelines for cardiovascular magnetic resonance imaging from the Korean Society of Cardiovascular Imaging-Part 2: interpretation of cine, flow, and angiography data. Korean J Radiol 2019;20:1477-1490

62. Lee JH, Ha EJ, Baek JH, Choi M, Jung SE, Yong HS. Implementation of Korean clinical imaging guidelines: a mobile app-based decision support system. Korean J Radiol 2019;20:182-189

63. Lee GY, Hwang JY, Kim NR, Kang Y, Choi M, Kim J, et al. Primary imaging test for suspected traumatic thoracolumbar spine injury: 2017 guidelines by the Korean Society of Radiology and National Evidence-Based Healthcare Collaborating Agency. Korean J Radiol 2019;20:909-915

64. Jo Y, Kim J, Park CH, Lee JW, Hur JH, Yang DH, et al. Guideline for cardiovascular magnetic resonance imaging from the Korean Society of Cardiovascular Imaging-Part 1: standardized protocol. Korean J Radiol 2019;20:1313-1333

65. Hong SH, Goo HW, Maeda E, Choo KS, Tsai IC; Asian Society of Cardiovascular Imaging Congenital Heart Disease Study Group. User-friendly vendor-specific guideline for pediatric cardiothoracic computed tomography provided by the Asian Society of Cardiovascular Imaging Congenital Heart Disease Study Group: part 1. Imaging techniques. Korean J Radiol 2019;20:190-204

66. Han S, Yoon SH, Lee W, Choi YH, Kang DY, Kang HR Management of adverse reactions to iodinated contrast media for computed tomography in Korean referral hospitals: a survey investigation. Korean J Radiol 2019;20:148-157

67. Hahn SY, Shin JH, Na DG, Ha EJ, Ahn HS, Lim HK, et al.; Korean Society of Thyroid Radiology (KSThR); Korean Society of Radiology. Ethanol ablation of the thyroid nodules: 2018 consensus statement by the Korean Society of Thyroid Radiology. Korean J Radiol 2019;20:609-620

68. Korean Liver Cancer Association (KLCA); National Cancer Center (NCC). 2018 Korean Liver Cancer Association-National Cancer Center Korea practice guidelines for the management of hepatocellular carcinoma. Korean J Radiol 2019;20:10421113

69. Kim JH, Baek JH, Lim HK, Ahn HS, Baek SM, Choi YJ, et al.; Guideline Committee for the Korean Society of Thyroid Radiology (KSThR) and Korean Society of Radiology. 2017 Thyroid Radiofrequency Ablation guideline: Korean Society of Thyroid Radiology. Korean J Radiol 2018;19:632-655

70. Kang MJ, Kim JH, Kim YK, Lee HJ, Shin KM, Kim JI, et al. 2018 Korean clinical imaging guideline for hemoptysis. Korean J Radiol 2018;19:866-871

71. Ha EJ, Lim HK, Yoon JH, Baek JH, Do KH, Choi M, et al.;
Korean Society of Thyroid Radiology (KSThR) and Korean Society of Radiology. Primary imaging test and appropriate biopsy methods for thyroid nodules: guidelines by Korean Society of Radiology and National Evidence-Based Healthcare Collaborating Agency. Korean J Radiol 2018;19:623-631

72. Cheng KL, Lin WC. RE: 2017 Thyroid Radiofrequency Ablation guideline: the Korean Society of Thyroid Radiology. Korean J Radiol 2018;19:1196-1197

73. Choi SJ, Jeong WK, Jo AJ, Choi JA, Kim MJ, Lee M, et al. Methodology for developing evidence-based clinical imaging guidelines: joint recommendations by Korean Society of Radiology and National Evidence-Based Healthcare Collaborating Agency. Korean J Radiol 2017;18:208-216

74. KSAR Study Group for Rectal Cancer. Essential items for structured reporting of rectal cancer MRI: 2016 consensus recommendation from the Korean Society of Abdominal Radiology. Korean J Radiol 2017;18:132-151

75. Yoon JH, Park JW, Lee JM. Noninvasive diagnosis of hepatocellular carcinoma: elaboration on Korean Liver Cancer Study Group-National Cancer Center Korea practice guidelines compared with other guidelines and remaining issues. Korean J Radiol 2016;17:7-24

76. Kim YJ, Yong HS, Kim SM, Kim JA, Yang DH, Hong YJ; Korean Society of Radiology; Korean Society of Cardiology. Korean guidelines for the appropriate use of cardiac CT. Korean J Radiol 2015;16:251-285

77. Kim YH, Bae JI, Jeon YS, Kim CW, Jae HJ, Park KB, et al. Korean guidelines for interventional recanalization of lower extremity arteries. Korean J Radiol 2015;16:696-722

78. Korean Liver Cancer Study Group (KLCSG); National Cancer Center, Korea (NCC). 2014 Korean Liver Cancer Study GroupNational Cancer Center Korea practice guideline for the management of hepatocellular carcinoma. Korean J Radiol 2015; 16:465-522

79. Yoon YE, Hong YJ, Kim HK, Kim JA, Na J0, Yang DH, et al. 2014 Korean guidelines for appropriate utilization of cardiovascular magnetic resonance imaging: a joint report of the Korean Society of Cardiology and the Korean Society of Radiology. Korean J Radiol 2014;15:659-688

80. Kim DH, Kim B, Jung C, Nam HS, Lee JS, Kim JW, et al. Consensus statements by Korean Society of Interventional Neuroradiology and Korean Stroke Society: hyperacute endovascular treatment workflow to reduce door-toreperfusion time. Korean J Radiol 2018;19:838-848

81. Na DG, Baek JH, Jung SL, Kim JH, Sung JY, Kim KS, et al.; Korean Society of Thyroid Radiology (KSThR) and Korean Society of Radiology. Core needle biopsy of the thyroid: 2016 consensus statement and recommendations from Korean Society of Thyroid Radiology. Korean J Radiol 2017;18:217237

82. Shin JH, Baek JH, Chung J, Ha EJ, Kim JH, Lee YH, et al.; Korean Society of Thyroid Radiology (KSThR) and Korean Society of Radiology. Ultrasonography diagnosis and imaging-based management of thyroid nodules: revised 
Korean Society of Thyroid Radiology consensus statement and recommendations. Korean J Radiol 2016;17:370-395

83. Lee JW, Hur JH, Yang DH, Lee BY, Im DJ, Hong SJ, et al. Guidelines for Cardiovascular Magnetic Resonance Imaging from the Korean Society of Cardiovascular Imaging-Part 2: Interpretation of Cine, Flow, and Angiography Data. Cardiovasc Imaging Asia 2019;3:113-124

84. Jo Y, Kim J, Park CH, Lee JW, Hur JH, Yang DH, et al. Guideline for cardiovascular magnetic resonance imaging from the Korean Society of Cardiovascular Imaging_Part 1: standardized protocol. Cardiovasc Imaging Asia 2019;3:74-92

85. Yun SJ, Jin W, Cho NS, Ryu KN, Yoon YC, Cha JG, et al. Shear-wave and strain ultrasound elastography of the supraspinatus and infraspinatus tendons in patients with idiopathic adhesive capsulitis of the shoulder: a prospective case-control study. Korean J Radiol 2019;20:1176-1185

86. Park SB, Kim MJ, Ko Y, Sim JY, Kim HJ, Lee KH. Structured reporting versus free-text reporting for appendiceal computed tomography in adolescents and young adults: preference survey of 594 referring physicians, surgeons, and radiologists from 20 hospitals. Korean J Radiol 2019;20:246255

87. Park J, Kim HK, Park EA, Park JB, Lee SP, Lee W, et al. Coronary computed tomography angiography for the diagnosis of vasospastic angina: comparison with invasive coronary angiography and ergonovine provocation test. Korean J Radiol 2019;20:719-728

88. Park AY, Kwon M, Woo OH, Cho KR, Park EK, Cha SH, et al. A prospective study on the value of ultrasound microflow assessment to distinguish malignant from benign solid breast masses: association between ultrasound parameters and histologic microvessel densities. Korean J Radiol 2019;20:759-772

89. Li T, Tang T, Yang L, Zhang X, Li X, Luo C. Coronary CT angiography with knowledge-based iterative model reconstruction for assessing coronary arteries and noncalcified predominant plaques. Korean J Radiol 2019;20:729738

90. Ko ES, Morris EA. Abbreviated magnetic resonance imaging for breast cancer screening: concept, early results, and considerations. Korean J Radiol 2019;20:533-541

91. Kang TW, Lee MW, Cha DI, Park HJ, Park JS, Bang WC, et al. Usefulness of virtual expiratory CT images to compensate for respiratory liver motion in ultrasound/CT image fusion: a prospective study in patients with focal hepatic lesions. Korean J Radiol 2019;20:225-235

92. Kang HJ, Lee JM, Jeon SK, Ryu H, Yoo J, Lee JK, et al. Microvascular flow imaging of residual or recurrent hepatocellular carcinoma after transarterial chemoembolization: comparison with color/power doppler imaging. Korean J Radiol 2019;20:1114-1123

93. Joo I, Kim SH, Lee DH, Han JK. Dynamic contrast-enhanced ultrasound of gastric cancer: correlation with perfusion CT and histopathology. Korean J Radiol 2019;20:781-790
94. Chung SR, Baek JH, Choi YJ, Sung TY, Song DE, Kim TY, et al. The role of core needle biopsy for the evaluation of thyroid nodules with suspicious ultrasound features. Korean J Radiol 2019;20:158-165

95. Zheng L, Li HL, Guo CY, Luo SX. Comparison of the efficacy and prognostic factors of transarterial chemoembolization plus microwave ablation versus transarterial chemoembolization alone in patients with a large solitary or multinodular hepatocellular carcinomas. Korean J Radiol 2018;19:237-246

96. Yoon JH, Lee JM, Klotz E, Woo H, Yu MH, Joo I, et al. Prediction of local tumor progression after radiofrequency ablation (RFA) of hepatocellular carcinoma by assessment of ablative margin using pre-RFA MRI and post-RFA CT registration. Korean J Radiol 2018;19:1053-1065

97. Park CJ, Kim KW, Lee HJ, Kim MJ, Kim J. Contrast-enhanced CT with knowledge-based iterative model reconstruction for the evaluation of parotid gland tumors: a feasibility study. Korean J Radiol 2018;19:957-964

98. Oddo S, Felix E, Mussap M, Giusti M. Quality of life in patients treated with percutaneous laser ablation for nonfunctioning benign thyroid nodules: a prospective singlecenter study. Korean J Radiol 2018;19:175-184

99. Min J, Park M, Choi JW, Jahng GH, Moon WJ. Inter-vendor and inter-session reliability of diffusion tensor imaging: implications for multicenter clinical imaging studies. Korean J Radiol 2018;19:777-782

100. Lee GY, Lee JW, Yeom JS, Kim KJ, Shin HI, Kang HS. The incidence of various types of systemic reactions related to epidural steroid injections: a prospective observational study. Korean J Radiol 2018;19:301-310

101. Kim Y, Kim SH, Song BJ, Kang BJ, Yim KI, Lee A, et al. Early prediction of response to neoadjuvant chemotherapy using dynamic contrast-enhanced MRI and ultrasound in breast cancer. Korean J Radiol 2018;19:682-691

102. Kim SY, Cho JY, Lee J, Hwang SI, Moon MH, Lee EJ, et al. Low-tube-voltage $\mathrm{CT}$ urography using low-concentrationiodine contrast media and iterative reconstruction: a multiinstitutional randomized controlled trial for comparison with conventional CT urography. Korean J Radiol 2018;19:11191129

103. Kim JW, Hong B, Shin JH, Park J, Kim JH, Gwon DI, et al. A prospective randomized comparison of a covered metallic ureteral stent and a double-J stent for malignant ureteral obstruction. Korean J Radiol 2018;19:606-612

104. Jung SL, Baek JH, Lee JH, Shong YK, Sung JY, Kim KS, et al. Efficacy and safety of radiofrequency ablation for benign thyroid nodules: a prospective multicenter study. Korean J Radiol 2018;19:167-174

105. Hahn SY, Shin JH, Ko EY, Bae JM, Choi JS, Park KW. Complementary role of elastography using carotid artery pulsation in the ultrasonographic assessment of thyroid nodules: a prospective study. Korean J Radiol 2018;19:992999 
106. Gwon DI, Ko GY, Kim JW, Ko HK, Yoon HK, Sung KB. Doublestent system with long duodenal extension for palliative treatment of malignant extrahepatic biliary obstructions: a prospective study. Korean J Radiol 2018;19:230-236

107. Goo HW. Image quality and radiation dose of high-pitch dual-source spiral cardiothoracic computed tomography in young children with congenital heart disease: comparison of non-electrocardiography synchronization and prospective electrocardiography triggering. Korean J Radiol 2018;19:1031-1041

108. Di Q. RE: efficacy and safety of radiofrequency ablation for benign thyroid nodules: a prospective multicenter study. Korean J Radiol 2018;19:542-543

109. Xie S, Li Q, Cheng Y, Zhang Y, Zhuo Z, Zhao G, et al. Impact of liver fibrosis and fatty liver on T1rho measurements: a prospective study. Korean J Radiol 2017;18:898-905

110. Min ZG, Niu C, Zhang QL, Zhang M, Qian YC. Optimal factors of diffusion tensor imaging predicting corticospinal tract injury in patients with brain tumors. Korean J Radiol 2017;18:844-851

111. Kim YP, Haam SJ, Lee S, Lee GD, Joo SM, Yum TJ, et al. Effectiveness of ambulatory tru-close thoracic vent for the outpatient management of pneumothorax: a prospective pilot study. Korean J Radiol 2017;18:519-525

112. Huh J, Kim KJ, Park SH, Park SH, Yang SK, Ye BD, et al. Diffusion-weighted MR enterography to monitor bowel inflammation after medical therapy in Crohn's disease: a prospective longitudinal study. Korean J Radiol 2017;18:162172

113. Feng R, Tong J, Liu X, Zhao Y, Zhang L. High-pitch coronary CT angiography at $70 \mathrm{kVp}$ adopting a protocol of low injection speed and low volume of contrast medium. Korean J Radiol 2017;18:763-772

114. Ahn SJ, Lee JM, Chang W, Lee SM, Kang HJ, Yang H, et al. Prospective validation of intra- and interobserver reproducibility of a new point shear wave elastographic technique for assessing liver stiffness in patients with chronic liver disease. Korean J Radiol 2017;18:926-935

115. Yoon SH, Park CM, Lee KH, Lim KY, Suh YJ, Im DJ, et al. Analysis of complications of percutaneous transthoracic needle biopsy using CT-guidance modalities in a multicenter cohort of 10568 biopsies. Korean J Radiol 2019;20:323-331

116. Lee KH, Lim KY, Suh YJ, Hur J, Han DH, Kang MJ, et al. Diagnostic accuracy of percutaneous transthoracic needle lung biopsies: a multicenter study. Korean J Radiol 2019;20:1300-1310

117. Kim H, Beck KS, Choe YH, Jung JI. Coronary-to-pulmonary artery fistula in adults: natural history and management strategies. Korean J Radiol 2019;20:1491-1497

118. Moon SH, Choi WH, Yoo IR, Lee SJ, Paeng JC, Jeong SY, et al. Prognostic value of baseline ${ }^{18} \mathrm{~F}$-fluorodeoxyglucose PET/ CT in patients with multiple myeloma: a multicenter cohort study. Korean J Radiol 2018;19:481-488

119. Hong MJ, Na DG, Baek JH, Sung JY, Kim JH. Impact of nodule size on malignancy risk differs according to the ultrasonography pattern of thyroid nodules. Korean J Radiol 2018;19:534-541

120. Park EA, Lee W, Kang DK, Kim SJ, Kim YJ, Kim Y, et al. Comparison of iohexol-380 and iohexol-350 for coronary CT angiography: a multicenter, randomized, double-blind phase 3 trial. Korean J Radiol 2016;17:330-338

121. Ha EJ, Moon WJ, Na DG, Lee YH, Choi N, Kim SJ, et al. A multicenter prospective validation study for the Korean thyroid imaging reporting and data system in patients with thyroid nodules. Korean J Radiol 2016;17:811-821

122. Kim SJ, Choi CG, Kim JK, Yun SC, Jahng GH, Jeong HK, et al. Effects of MR parameter changes on the quantification of diffusion anisotropy and apparent diffusion coefficient in diffusion tensor imaging: evaluation using a diffusional anisotropic phantom. Korean J Radiol 2015;16:297-303

123. Kim DW, Jung SL, Kim J, Ryu JH, Sung JY, Lim HK. Comparison between ultrasonography and computed tomography for detecting the pyramidal lobe of the thyroid gland: a prospective multicenter study. Korean J Radiol 2015;16:402-409

124. Kwak JY, Jung I, Baek JH, Baek SM, Choi N, Choi YJ, et al.; Korean Society of Thyroid Radiology (KSThR); Korean Society of Radiology. Image reporting and characterization system for ultrasound features of thyroid nodules: multicentric Korean retrospective study. Korean J Radiol 2013;14:110-117

125. Na DG, Lee JH, Jung SL, Kim JH, Sung JY, Shin JH, et al.; Korean Society of Thyroid Radiology (KSThR); Korean Society of Radiology. Radiofrequency ablation of benign thyroid nodules and recurrent thyroid cancers: consensus statement and recommendations. Korean J Radiol 2012;13:117-125

126. Moon WJ, Baek JH, Jung SL, Kim DW, Kim EK, Kim JY, et al.; Korean Society of Thyroid Radiology (KSThR); Korean Society of Radiology. Ultrasonography and the ultrasound-based management of thyroid nodules: consensus statement and recommendations. Korean J Radiol 2011;12:1-14

127. Peña CS, Saini S, Baron RL, Hamm BA, Morana G, Caudana $\mathrm{R}$, et al. Detection of malignant primary hepatic neoplasms with gadobenate dimeglumine (Gd-BOPTA) enhanced T1weighted hepatocyte phase MR imaging: results of offsite blinded review in a phase-II multicenter trial. Korean $\mathrm{J}$ Radiol 2001;2:210-215

128. Chen SQ, Huang M, Shen YY, Liu CL, Xu CX. Abbreviated MRI protocols for detecting breast cancer in women with dense breasts. Korean J Radiol 2017;18:470-475

129. Kang TW, Lee MW, Song KD, Kim M, Kim SS, Kim SH, et al. Added value of contrast-enhanced ultrasound on biopsies of focal hepatic lesions invisible on fusion imaging guidance. Korean J Radiol 2017;18:152-161

130. Goo HW. Comparison of chest pain protocols for electrocardiography-gated dual-source cardiothoracic CT in children and adults: the effect of tube current saturation on radiation dose reduction. Korean J Radiol 2018;19:23-31

131. Kim SK, Lee KA, Sauk S, Korenblat K. Comparison of 
transjugular intrahepatic portosystemic shunt with covered stent and balloon-occluded retrograde transvenous obliteration in managing isolated gastric varices. Korean J Radiol 2017;18:345-354

132. Kim SS, Jin GY, Li YZ, Lee JE, Shin HS. CT quantification of lungs and airways in normal Korean subjects. Korean J Radiol 2017; 18:739-748

133. Korean Society of Abdominal Radiology. Diagnosis of hepatocellular carcinoma with gadoxetic acid-enhanced MRI: 2016 consensus recommendations of the Korean Society of Abdominal Radiology. Korean J Radiol 2017;18:427-443

134. Shah HJ, Keraliya AR, Jagannathan JP, Tirumani SH, Lele VR, DiPiro PJ. Diffuse large B-cell lymphoma in the era of precision oncology: how imaging is helpful. Korean $\mathrm{J}$ Radiol 2017; 18:54-70

135. Seo M, Ryu JK, Jahng GH, Sohn YM, Rhee SJ, Oh JH, et al. Estimation of $\mathrm{T}^{*}$ relaxation time of breast cancer: correlation with clinical, imaging and pathological features. Korean J Radiol 2017;18:238-248

136. Braschi-Amirfarzan M, Tirumani SH, Hodi FS Jr, Nishino M. Immune-checkpoint inhibitors in the era of precision medicine: what radiologists should know. Korean J Radiol 2017; 18:42-53

137. Park HS, Baek JH, Choi YJ, Lee JH. Innovative techniques for image-guided ablation of benign thyroid nodules: combined ethanol and radiofrequency ablation. Korean J Radiol 2017; 18:461-469

138. Fütterer JJ. Multiparametric MRI in the detection of clinically significant prostate cancer. Korean J Radiol 2017;18:597-606

139. Chang W, Lee JM, Lee SM, Han JK. No-touch radiofrequency ablation: a comparison of switching bipolar and switching monopolar ablation in ex vivo bovine liver. Korean J Radiol 2017; 18:279-288

140. Kim HJ, Bang JI, Kim JY, Moon JH, So Y, Lee WW. Novel application of quantitative single-photon emission computed tomography/computed tomography to predict early response to methimazole in Graves' disease. Korean J Radiol 2017; 18:543-550

141. Lee JW, Jeong YJ, Lee G, Lee NK, Lee HW, Kim JY, et al. Predictive value of cardiac magnetic resonance imagingderived myocardial strain for poor outcomes in patients with acute myocarditis. Korean J Radiol 2017;18:643-654

142. Lee JW, Kim HY, Goo JM, Kim EY, Lee SJ, Kim TJ, et al. Radiological report of pilot study for the Korean Lung Cancer Screening (K-LUCAS) project: feasibility of implementing lung imaging reporting and data system. Korean J Radiol 2018; 19:803-808

143. Park JE, Han K, Sung YS, Chung MS, Koo HJ, Yoon HM, et al. Selection and reporting of statistical methods to assess reliability of a diagnostic test: conformity to recommended methods in a peer-reviewed journal. Korean J Radiol 2017;18:888-897

144. Park HS, Baek JH, Park AW, Chung SR, Choi YJ, Lee JH. Thyroid radiofrequency ablation: updates on innovative devices and techniques. Korean J Radiol 2017;18:615-623

145. Yoon IS, Shin JH, Han K, Kim PN, Kim KH, Kang YK, et al. Ultrasound-guided intraoperative radiofrequency ablation and surgical resection for liver metastasis from malignant gastrointestinal stromal tumors. Korean J Radiol 2018;19:5462

146. Aslaner R, Pekcevik Y, Sahin H, Toka 0. Variations in the origin of inferior phrenic arteries and their relationship to celiac axis variations on CT angiography. Korean J Radiol 2017;18:336-344

147. Semionov A, Kosiuk J, Ajlan A, Discepola F. Imaging of thoracic wall abnormalities. Korean J Radiol 2019;20:14411453

148. Lee JW, Park CH, Lee SM, Jeong M, Hur J. Planting seeds into the lung: image-guided percutaneous localization to guide minimally invasive thoracic surgery. Korean J Radiol 2019;20:1498-1514 